\title{
Ébli, Gábor. National Museums and Civic Patrons: Practices of Cultural Accumulation in Central and Eastern Europe. Budapest: L'Harmattan, 2020.
}

\author{
Reviewed by Oliver A. I. Botar, University of Manitoba, Winnipeg, Canada \\ Oliver.Botar@umanitoba.ca
}

Gábor Ébli's National Museums and Civic Patrons is an anthology of previously published essays and chapters, and previously presented conference papers and talks by the author, a professor of Art History at Moholy-Nagy University of Art and Design in Budapest. Ébli is surely the most prolific and erudite scholar on museums and collecting in Hungary, and thus has much to offer. In a real sense, this book has too much to offer: the anthology (which is how I am going to refer to this book as a whole), while containing an embarrassment of riches both in content and interpretation, suffers from a multiple identity crisis, or rather, from a lack of focus.

There are at least two books worth of texts in this anthology. One might delineate these two potential volumes based on Ébli's own sections. One of these books could be on the history of Hungarian museums and museum policy from the early nineteenth-century to the 2010s, and it is contained in Parts I and II of the book as published: "Integration and Isolation in Hungarian Museum History and Art Patronage" and "Current Museum Issues in Central and Eastern Europe." This is a long-overdue study that I thoroughly enjoyed reading, and which - despite avoidable duplications - hangs together as an organic whole. One of the things that makes this first book so interesting and valuable is that it includes welcome and sometimes in-depth parallels, contrasts and comparisons with the museum history and museum-policy history of other countries of the region, in the two "halves" of Central Europe. This includes pioneering research, a comparative approach that, until very recently, has been all too rare in the art historical literature of the region. I say "until recently," because just as Ébli's book appeared, the anthology of texts entitled The Museum Age in Austria-Hungary: Art and Empire in the Long Nineteenth Century (Pennsylvania University Press, 2020), was also published. In that book Matthew Rampley, Markian Prokopovych and Nóra Veszprémi cover this comparative territory quite exhaustively, and Veszprémi parallels Ébli on writing about Hungarian museological practices. Unlike in The Museum Age, in Ébli's book the comparative material is essentially supplementary to the Hungarian focus, rendering the anthology's title misleading. In short, this is not a book that covers the entirety of East-Central Europe (not to mention that the AustroGerman context is also dealt with extensively), and should have been titled more carefully.

The other book of Ébli's that might have been produced on the basis of his anthology would have been a volume of essays on private collections, including also interviews with private collectors of Hungarian art both in Hungary and abroad. While the material is fascinating and I read through these "chapters" like an addict, hungry for each new description and/or interview, these texts do not cohere well with (based on the title, such as it is), the main thrust of

(cc) BY

ULLS D-Serle
New articles in this journal are licensed under a Creative Commons Attribution 4.0 International License.

This journal is published by the University Library System of the University of Pittsburgh as part of its D-Scribe Digital Publishing Program and is cosponsored by the University of Pittsburgh Press 
book, the focus on "National Museums," and therefore I would have left these texts (Parts III and IV) out; not to mention the fact that in 2006 Ébli already published a wonderful book with fiftynine profiles of Hungarian collectors and collections (Magyar Mügyüjtemények 1945-2005, Budapest, Enciklopédia Kiadó). But even this hypothetical second volume would lack coherence due to the fact that it includes chapters on Hungarian gallery-owners as well as "civic," i.e., "private" collectors. How do discussions of art dealers relate to cultural accumulation rather than to cultural marketing and sales, that is, cultural dispersal? Furthermore, among these gallery owners we also find expat dealers of Hungarian origin who did not focus on marketing Hungarian art or have only barely engaged in such marketing. So even this sub-section of a subsection does not really hang together. Therefore, I am compelled to revise the hypothetical reworking of this anthology even further: there is a body of material in it that could form the basis for a third volume, one on Hungarian art dealers, both at home and abroad, and not necessarily with a focus on the marketing of Hungarian art.

What is included in a given volume, and what is not, is important. And how that volume is entitled, and therefore framed, is also significant. The title should reflect what is actually contained in the book. An accurate title for this book would have been something like "Hungarian Museums and Museum Policy in a Regional Context - Hungarian Art Collectors and Art Dealers at Home and Abroad: An Anthology of Writings," for this is what the volume actually contains. By endowing it with a title that suggests an overall coherence around a single theme, the publisher is doing a disservice both to the material and to the author. There is nothing objectionable about the collected re-publication of otherwise dispersed article and chapters by a given author, even including previously unpublished papers presented at conferences: it is a tried-and-true method of knowledge distribution, especially when the author is as important as Ébli is. But the book should be clearly marketed as such.

The job of the reviewer becomes difficult in this situation. Now that I have tried to clarify a few points concerning the structure, content and framing of the anthology, what is it that I should do? Should I critique it on the basis of the title, one that, as mentioned, promises a coherent unity but does not deliver on that promise? (I have already done that.) Or should I take the suggestion of a coherent unity implied in the title and extract from that title the part of the anthology that potentially embodies that unity, and critique it? Given the importance and brilliance of the latter, I will focus this review on it, that is, on the Hungarian-centered content contained in Parts I and II on national museums and cultural accumulation policies within a regional context. This "virtual book" within a book is an original, long-overdue and outstanding study on the subject of the history of Hungarian museums and museum policy within the regional context of East-Central Europe, sometimes also specifically referring to Austria and Germany. This narrower "book" is well researched, well written, and apart from some minor stylistic and grammatical issues, very well translated into English. And while the comparative analysis of regional museum policies of the interwar period is largely missing (which is unfortunate, as The Museum Age in Austria-Hungary also stops at the First World War), it is resplendent with the deep erudition and broad, international purview of this highly intelligent scholar. This "book," a deep dive into the history of state-sponsored collecting and museum policy in Hungary within a regional context, is both a pleasure to read and highly enlightening.

I have mentioned that the comparative analysis of the interwar period is largely lacking, but also missing is an update concerning the past five to ten years. Many of the museological topics covered since 1989 seem to be current up to about 2010-2015. We know, however, that due to a major political shift around 2015 towards the Right - much has changed since that time. 
Therefore, it would have been useful to at least include footnotes indicating major developments since 2015, rather than leaving the impression that the book, published in 2020, actually covers the period up to the time of its publication. This, again, is a question of strategy, both of the author and of the publisher.

I do not wish to dwell on the negative, however. There are so many insights, new ideas and fresh research results presented in this "book," that it is difficult to choose which of these to highlight. One example is the discussion of the late eighteenth- to the early nineteenth-century origins of Hungarian museology and collecting, and the complex reasons for its emergence. Ébli is not interested in presenting the type of anachronistic, nationalist perspective on these developments as attempts at nation building. Instead, his discussion takes full account of the realities of the Hungarian Kingdom of that time: its multi-ethnic, German-dominated character, the internationalist as well as nationalist ambitions of the protagonists, and the successes as well as failures of a politically dynamic century. This is anti-ethnocentric historiography at its best, and it is all the more noteworthy given the current Central European context of rampant, narrow and anachronistic ethnocentrism.

One of the felicitous motifs running through this "book" (indeed through the anthology as a whole), is the tension between the collecting of Hungarian art versus the collecting of international art. Ébli consistently weaves this theme through the narrative, thereby both historicizing the vicissitudes of Hungarian history (when was it possible to collect important international art? When was it not? When was it fashionable? When was it not?) and problematizes this tension, thereby successfully embedding the history of collecting within the country into the history of European, and as he puts it, "universal" collecting in general. This is crucial, especially in a country that has gone through periods of alternately turning outward and inward the way that Hungary has. What I missed, however, was a deeper discussion of the origins of this dynamic. In my view, the lack of a Western-European-style colonialist past in the country and the Monarchy is a factor that both contributed to its tendency toward provincial conservatism and xenophobia, and spares it of the sins of such a colonialist past which, despite some similarities, is to be distinguished from Hungary's - relative to Western European colonialism - mild Magyarization policies of the late nineteenth-century. (There were AustroHungarian colonial efforts in the Balkans, but those I would argue, reinforced provincialism, as the Balkans were adjacent.)

Regarding the wealth of ways in which Ébli contextualizes the accumulation and promotion of Hungarian art within the balkanized context of the Post-World-War-One era, his analysis of the overall dynamics is both insightful and apt. Consider, for example, this discussion: "Instead of collecting the art of one another, the art fanatics of each East European country strive to acquire key works of their national contemporary art scene and promote these into the 'Western', or international canon of art. This attitude can be regarded as a therapy of inferiority complexes, where the collectors in each East European nation pursue the same strategy of trying to elevate their own national art to the international level, skipping the regional level, without noting that every other nation in the region struggles the same way and that doing this jointly would actually earn much more attention in the world" (84). I have rarely read a more trenchant analysis of inter-East-Central-European dynamics, an analysis that could also be applicable to fields other than art colleting.

A final issue I have with the way the anthology as a whole was assembled is that the articles, chapters and talks in it seem to have been published as they were originally published or given, that is, they were not edited in order to avoid redundancy and promote overall coherence. 
Unless the book is being marketed as an anthology of key texts by a given author (and this book is clearly not intended to be that), such a lack of editing is a mistake as it results in more words and less clarity. While it is always good to have a refresher of the outlines of the exciting history of collecting in Hungary, it is ultimately unnecessary to repeat information already presented in other chapters.

In summary, while this anthology is brimming over with deep, new research, trenchant analysis and brilliant insights, it also suffers from multiple identity crises engendered by a seemingly uncritical accumulation of only loosely related groups of texts, and an overall mistitling of even the accumulation that is presented. Furthermore, little or no effort was made to avoid redundancy among the chapters. Also, even though this book was published in 2020, no effort was made to update the subjects covered in it since about 2010 to 2015. More thoughtful framing and editing could have resulted in a shorter yet more coherent presentation of the outstanding material and analytical skills that Gabor Ébli clearly possesses in abundance. And he would have had material left over to begin to write two more books, one on the history of private collecting in Hungary and the collection of Hungarian art both at home and abroad, and one on Hungarian gallery owners, both at home and abroad. In fact, Ébli could still produce those books! Were he to do so, I would be the first in line to acquire and read them. 